Parrots of the Wild 
The publisher gratefully acknowledges the generous support of the General Endowment Fund of the University of California Press Foundation. 


\section{Parrots of the Wild}

A Natural History of the World's

Most Captivating Birds

CATHERINE A. TOFT AND TIMOTHY F. WRIGHT

Foreword by James D. Gilardi

IN COLLABORATION WITH THE WORLD PARROT TRUST

뚜

UNIVERSITY OF CALIFORNIA PRESS 
University of California Press, one of the most distinguished university presses in the United States, enriches lives around the world by advancing scholarship in the humanities, social sciences, and natural sciences. Its activities are supported by the UC Press Foundation and by philanthropic contributions from individuals and institutions. For more information, visit www.ucpress.edu.

University of California Press

Oakland, California

(C) 2015 Catherine A. Toft and James D. Gilardi

Library of Congress Cataloging-in-Publication Data

Toft, Catherine Ann, I950-20II, author.

Parrots of the wild : a natural history of the world's most captivating birds / Catherine A. Toft and Timothy F. Wright in collaboration with the World Parrot Trust ; foreword by James

D. Gilardi. - First edition.

pages $\mathrm{cm}$

Includes bibliographical references and index.

ISBN 978-0-520-23925-8 (cloth : alk. paper) — ISBN 0-520-23925-3 (cloth : alk. paper) -

ISBN 978-0-520-96264-4 (ebook) — ISBN 0-520-96264-8 (ebook)

I. Parrots. I. Wright, Timothy F., I967-author. II. World Parrot Trust. III. Title.

QL696.P7T64 20I5

598.7 'I-dc23

2015001989

Printed in China

$\begin{array}{llllllllll}24 & 23 & 22 & 2 \text { I } & 20 & \text { I9 } & \text { I8 } & \text { I7 } & \text { I6 } & \text { I5 } \\ \text { IO } & 9 & 8 & 7 & 6 & 5 & 4 & 3 & 2 & \text { I }\end{array}$

The paper used in this publication meets the minimum requirements of ANSI/NISO Z39.48-I992 (R 2002) (Permanence of Paper). 
To Dr. Don Merton (1939-2011)

For his tireless devotion to the conservation of parrots;

To Keiki, Mickey, and Freestone

Cockatoos all

For starting me on this path.

All royalties from the sales of this book will be donated to the World Parrot Trust to support research on and conservation of wild parrots. 
This page intentionally left blank 